\title{
PENGEMBANGAN MEDIA INOVATIF BOARD GAME MONOPOLI MATERI KESEHATAN PADA PEMBELAJARAN PENDIDIKAN JASMANI OLAHRAGA DAN KESEHATAN
}

\author{
I Ketut Budaya Astra', I Gede Suwiwa², Hafidz Almada ${ }^{3}$ \\ 1,2,3 Prodi Pendidikan Jasmani Kesehatan Dan Rekreasi Universitas Pendidikan Ganesha-Bali \\ E-mail: budaya.astra@undiksha.ac.id¹, gede.suwiwa@undiksha.ac.id², \\ hafidzalmada81@gmail.com ${ }^{3}$ \\ DOI: https://doi.org/10.36526/kejaora.v5i2.931
}

\begin{abstract}
ABSTRAK
Tujuan penelitian ini adalah 1) menggambarkan proses rancang bangun media inovatif pada mata pelajaran PJOK SMP kelas VIII, dan 2) mengetahui hasil validasi media inovatif. Penelitian ini menggunakan model pengembangan model ADDIE. Langkah-langkah pengembangannya meliputi: analisis (Analyze), perencanaan (Design), pengembangan (Development), penerapan (Implementation), evaluasi (Evaluation). Setelah mencapai tahap pengembangan dihasilkan produk awal kemudian divalidasi oleh seorang ahli isi mata pelajaran, ahli desain pembelajaran, dan ahli media pembelajaran. Metode pengumpulan data yang digunakan dalam penelitian ini adalah metode angket/kuesioner. Pada penelitian ini, kuesioner digunakan untuk mengumpulkan data hasil review ahli. Data dianalisis dengan teknik analisis deskriptif kualitatif dan analisis deskriptif kuantitatif. Hasil penelitian menunjukan proses rancang bangun Media Inovatif terdiri dari lima tahapan model ADDIE yaitu analisis (Analyze), perancangan (Design), pengembangan (Development), penerapan (Implementation), dan evaluasi (Evaluation). Hasil validasi multimedia interaktif dari: 1) uji ahli isi berada pada nilai $87 \%$ (baik); 2) uji ahli desain pembelajaran pada nilai $93 \%$ (sangat baik); 3) uji ahli media pembelajaran pada nilai $93 \%$ (sangat baik).
\end{abstract}

Kata Kunci: Model ADDIE, Media Inovatif, Pengembangan

\section{PENDAHULUAN}

Kesehatan merupakan hal yang sangat penting bagi semua manusia karena tanpa kesehatan yang baik, maka setiap manusia akan sulit dalam melaksanakan aktivitasnya sehari-hari. Kesehatan pada hakikatnya merupakan keadaan sehat, baik secara fisik, mental, spiritual maupun sosial yang memungkinkan setiap orang untuk hidup produktif. Kesehatan ini dapat diperoleh dari kebiasaan atau pola hidup sehat.

Pola hidup sehat merupakan kebiasaan-kebiasaan melakukan sesuatu baik itu makanan, perilaku secara sehat sehingga terhindar dari gangguan segala macam penyakit, baik penyakit fisik maupun non fisik. Mencegah penyakit melalui pola hidup sehat bukan hal yang sederhana untuk dilakukan, terutama oleh peserta didik apabila tidak memiliki pengetahuan tentang cara melakukannya dan mengetahui bahaya dari penyakit yang disebabkan oleh pola hidup tidak sehat. Sebagaicontoh, penggunaan zat adiktif maupun narkoba dapat menyebabkan kecanduan dan merusak organ fisik seperti otak dan jantung, serta penyakit-penyakit menular seksual akibat perilaku seks bebas.

$$
\text { Rozak \& Sayuti }
$$

mengemukakan bahwa berdasarkan undangundang nomor 22 tahun 1997 pasal 2 narkotika dibagi menjadi 3 jenis berdasarkan golongan. Narkotika golongan I, Narkotika golongan III, Narkotika golongan III.

Narkoba merupakan obat berbahaya yang jika dimasukkan ke dalam tubuh manusia, baik melalui cara dihirup maupun dengan cara disuntikkan, dapat mengubah pikiran, suasana hati, atau perasaan dan perilaku seseorang. Narkoba merupakan obat berbahaya yang jika dimasukkan ke dalam tubuh manusia, baik melalui cara dihirup maupun dengan cara disuntikkan, dapat mengubah pikiran, suasana hati, atau perasaan dan perilaku seseorang 
(Wiradihardja \& Syarifudin, 2016). Narkoba pada awalnya adalah obat yang digunakan untuk keperluan pengobatan dan pengembangan ilmu pengetahuan, namun disalahgunakan oleh beberapa orang demi keuntungan pribadi yang justru dapat merusak dirinya sendiri dan juga lingkungannya. Saat ini penyalahgunaan narkoba di Indonesia sudah sangat merajalela. Hal ini terlihat dengan semakin banyaknya pengguna narkoba dari semua kalangan dan peredaran narkoba yang terus meningkat. Namun yang lebih memprihatinkan, penyalahgunaan narkoba saat ini justru banyak dari kalangan remaja, yaitu pelajar. Padahal mereka merupakan generasi penerus bangsa yang nantinya akan menjadi pemimpin-pemimpin di negeri ini.

Pendidikan merupakan salah satu pihak yang berkewajiban dan bertanggung jawab dalam upaya pencegahan penyalahgunaan narkoba di kalangan pelajar. Karena pelajar merupakan objek yang secara emosional masih labil, sehingga sangat rentan untuk menggunakan narkoba. Mulai dari rasa ingin tahu, mau coba-coba, ikutikutan teman, rasa solidaritas grup yang kuat dan memilih lingkungan yang salah sampai dengan faktor keluarga yang kurang perhatian dan lain-lain. Selain karena objek sasarannya yang labil, sekolah juga merupakan tempat yang rentan untuk peredaran narkoba. Apabila dalam pembelajaran peserta didik tidak diberikan materi pendidikan kesehatan, maka dikhawatirkan mereka akan terjerumus dalam perilaku yang tidak sehat, sehingga membentuk kepribadian yang acuh terhadap kesehatan. Hal ini menunjukkan betapa pentingnya pemberian materi tentang kesehatan kepada peserta didik.

PJOK merupakan media untuk mendorong pertumbuhan fisik, perkembangan psikis, keterampilan motorik, pengetahuan dan penalaran, penghayatan nilai-nilai (sikap-mental-emosionalsportivitas-spiritual-sosial) serta pembiasaan hidup sehat yang bermuara untuk merangsang pertumbuhan dan perkembangan kualitas fisik dan psikis yang seimbang (Depdiknas, 2006). Menurut Dimyati \& Mudjiono (2006) pembelajaran memuat titik interaksi, antara pembelajar dan pelajar berorientasi pada sasaran belajar, berakhir dengan evaluasi.

Fungsi media pembelajaran adalah sebagai alat bantu mengajar, yakni menunjang penggunaan metode mengajar yang diterapkan maupun dipergunakan guru. Salah satunya adalah media pembelajaran yang bersifat Visual, dalam hal ini dapat menggunakan media cetak sebagai pelengkap media pembelajaran yanglebih interaktif. Agar lebih menyenangkan, maka guru dapat mengemas materi menjadi sebuah bahan ajar yang menarik, dengan mengaplikasikan media inovatif dalam dunia pendidikan, maka dapat diciptakan media pembelajaran berbasis Game.

Game edukasi adalah permainan yang bertujuan untuk memancing minat belajar anak terhadap materi pelajaran sambil bermain, sehingga dengan perasaan senang diharapkan anak bisa lebih mudah memahami materi pelajaran yang disajikan. Kuswardayanmenjelaskan bahwa game edukasi merupakan salah satu tema permainan yang berusaha memberikan nilai edukasi dalam sebuah permainan, sehingga permainan yang awalnya hanya berfungsi sebagai media penghibur, akhirnya juga dapat digunakan sebagai media pembelajaran atau pelatihan.

Kata media berasal dari bahasa latin medius yang secara harfiah berarti tengah, perantara atau pengantar. Dalam bahasa Arab media adalah perantara atau pengantar pesan dari pengirim kepada penerima pesan (Arsyad, 2009).Media inovatif board game ini dipilih karena beberapa alasan. Pertama, hampir semua anak pada saat ini lebih aktif bermain game, baik itu melalui handphone maupun komputer, sebab bagi anak-anak game merupakan suatu hal yang menyenangkan dan sangat mereka sukai. Melalui sesuatu yang disukai diharapkan siswa akan lebih tertarik untuk belajar sehingga proses belajar akan lebih mudah dipahami. Kedua, dengan menggunakan media inovatif siswa dapat dengan mudah mengingat materi yang diberikan.

Dilihat dari tingkat ketercapaian tujuan pembelajaran di tingkat sekolah menengah, khususnya SMP, untuk mata pelajaran PJOK 
(Pendidikan Jasmani, Olahraga, dan Kesehatan) tergolong relatif rendah. Hal itu terlihat dari hasil wawancara dengan narasumber, yaitul Gusti Nyoman Astawa, S.Pd. Beliau merupakan guru mata pelajaran PJOK kelas VIII di SMP. Beliau menyatakan antusian belajar siswa khususnya pada materi kesehatan NAPZA masih rendah.

Berdasarkan uraian di atas, mengingat begitu pentingnya materi kesehatan NAPZA bagi peserta didik serta kendala yang dialami di dalam pembelajaran terkait media, maka sangatlah diperlukan suatu pengembangan media yang dapat mengakomodasi kebutuhan peserta didik dalam meningkatkan motivasi belajarnya, sehingga membuat peserta didik SMP kelas VIII dalam mengikuti pelajaran PJOK materi kesehatan dapat menyerap materi yang diajarkan dengan baik dan tujuan pembelajaran dapat tercapai serta membentuk kepribadian yang sadar akan kesehatan. Oleh karena itu, dalam skripsi ini digagas sebuah penelitian yang berjudul "Pengembangan Media Inovatif Board Game Monopoli Materi Kesehatan Pada Pembelajaran Pendidikan Jasmani Olahraga Dan Kesehatan Pada Siswa Kelas VIII Sekolah Menengah Pertama".

\section{METODE}

Prosedur penelitian ini mengadaptasi model pengembangan ADDIE. "Model ADDIE dikembangkan oleh Dick and Carey (1996) untuk merancang sistem pembelajaran" (Mulyatiningsih, 2014).

Jenis penelitian yang digunakan adalah penelitian pengembangan. Penelitian dan pengembangan adalah suatu proses atau langkah-langkah untuk mengembangkan suatu produk baru atau menyempurnakan produk yang telah ada. Yang dimaksud dengan produk dalam hal ini tidak selalu berbentuk software (program pengolahan data, pembelajaran di kelas, perpustakaan atau laboratorium, ataupun model-model pendidikan, pembelajaran pelatihan, bimbingan, evaluasi, manajemen, dan lain-lain), tetapi bisa juga berupa sebuah perangkat keras (hardware) sepertibuku, modul, alat bantu pembelajaran di kelas dan laboratorium. Penelitian seperti ini akan lebih memfokuskan tujuan untuk menghasilkan dan mengembangkan produk yang layak digunakan sesuai dengan kebutuhan.

Model pembuatan produk dalam penelitian pengembangan ini adalah model ADDIE. Pemilihan model ini didasarkan atas pertimbangan bahwa model ini disusun secara terprogram dengan urutan-urutan kegiatan yang sistematis dalam upaya pemecahan masalah belajar yang berkaitan dengan sumber belajar yang sesuai dengan kebutuhan dan karakteristik pebelajar.

Model ADDIE meliputi 5 tahap yaitu: (1) analisis (analyze), (2) desain (design), (3) pengembangan (development), implementasi (implementation), (5) evaluasi (evaluation). Pada tahap evaluasi terdapat 4 tahapan yaitu: (1) evaluasi ahli/pertimbangan ahli, (2) evaluasi satu lawan satu, (3) evaluasikelompok kecil, dan (4) evaluasi lapangan, (Tegeh \& Jampel, 2017).

\section{HASIL DAN PEMBAHASAN}

Hasil pengembangan produk media berbasis board game monopoli mengunakan model ADDIE meliputi 5 tahap yaitu; (1) tahap Analisis, (2) desain, (3) pengembangan, (4) implementasi, (5) evaluasi. Langkah validasi bahan ajar mengadopsi model evaluasi fomatif Dick Carey, and Carey yang meliputi empat tahapan yaitu : (1) evaluasi pakar atau ahli, (2) uji coba perorangan, (3) uji coba kelompok kecil, dan (4) uji coba kelompok besar.

Menurut Olson (dalam Sudarma \& Oka, 2008) "media sebagai teknologi untuk menyajikan, merekam, membagi dan mendistribusikan simbol melalui rangsangan indra tertentu".

Klasifikasi media menurut Ibrahim et al. (2004)

a) Media tanpa proyeksi dua dimensi: gambar, bagan, poster, grafik, peta datar.

b) Media tanpa proyeksi tiga dimensi: benda sebenarnya, model, boneka.

c) Media audio: radio, cassette tape recorder.

d) Media dengan proyeksi: OHP, film, slide.

e) Televisi, video, komputer.

Latuheru (dalam Fiktiany, 2007) menyatakan terdapat empat (4) keunggulan 
Jurnal Kejaora: Jurnal Kesehatan Jasmani dan Olah Raga

ISSN: 2541-5042 (Online)

ISSN: 2503-2976 (Print)

Volume 5 Nomor 2, Edisi November 2020

media permainan. Adapun keunggulannya dijelaskan sebagai berikut: 1) Melalui permainan, anak didik dapat segera melihat atau mengetahui hasil dari pekerjaan mereka, 2) Biaya untuk latihan dapat dikurangi dengan adanya permainan, 3) Permainan dapat memberikan pengalaman-pengalaman yang nyata dan dapat diulangi sebanyak yang dikehendaki, 4) Ada berbagai macam kemungkinan variansi dalam permainan sehingga memungkinkan penggunaanya dalam segala bidang.

Menurut Sadiman, et al. (2011) untuk tujuan praktis, ada beberapa jenis tujuan media yang lazim digunakan di Indonesia dalam kegiatan belajar mengajar yaitu: Media Grafis, Media Audio, Media Proyeksi Diam.

Berdasarkan hasil observasi yang telah dilakukan menunjukkan bahwa pada proses pembelajaran pendidikan jasmani olahraga dan kesehatan khususnya pada pembelajaran kesehatan, tidak menggunakan media pembelajaran. Selain itu dari hasil wawancara yang telah dilakukan kepada guru Penjasorkes di SMP, diketahui bahwa guru jarang memberikan pelajaran teori kesehatan di kelas dan lebih cendrung melaksanakan pembelajaran praktek.

Dari penelitian pendahuluan, ditemukan beberapa hal sebagai berikut:

a) Guru menyampaikan bahwa dalam mata pelajaran penjasorkes siswa hanya melakukan praktek olahraga dilapangan

b) Guru menyatakan minat belajar siswa terhadap pembelajaran kesehatan masih rendah.

c) Guru menyatakan perlunya media pembelajaran kesehatan berupa board game monopoli.

d) Guru menyatakan perlu dikembangkan media pembelajaran yang inovatif, kreatif untuk memotivasi siswalebih tertarik mengikuti kegiatan di kelas.

Penyajian dan Analisis Data akan dipaparkan data yang diperoleh dari hasil uji coba berdasarkan jumlah subjek. Subjek pengembangan media board game adalah para Ahli. Rincian subjek penelitian adalah 1) satu orang ahli isi, 2) satu orang ahli media, 3) satu orang ahli desain.

Masukan dari ahli isi materi adalah isi media sudah sesuai dengan materi 
Jurnal Kejaora: Jurnal Kesehatan Jasmani dan Olah Raga

ISSN: 2541-5042 (Online)

ISSN: 2503-2976 (Print)

Volume 5 Nomor 2, Edisi November 2020

Beberapa hasil penelitian yang relevan dalam penelitian ini yaitu, Penelitian Rohayati (2018) yang berjudul "Pengembangan Media Inovatif Berbasis Game Edukasi Materi Kesehatan pada Mata Pelajaran Pendidikan Jasmani Olahraga dan Kesehatan Kelas X SMA Negeri 1 Sukasada Tahun Pelajaran 2017/2018". Hasil penelitian menunjukkan bahwa validasi bahan ajar ditinjau dari aspek isi/materi memperoleh presentase $90 \%$ dengan kualifikasi sangat baik, aspek desain pembelajaran memperoleh presentase $96 \%$ dengan kualifikasi sangat baik, aspek media pembelajaran memperoleh presentase $86 \%$ dengan kualifikasi baik.

Penelitian Maulana (2016) yang berjudul "Pengembangan Multimedia Interaktif Materi Pola Hidup Sehat Pada Mata Pelajaran Pendidikan Jasmani Olahraga Dan Kesehatan". Hasil penelitian menunjukkan bahwa validasi bahan ajar ditinjau dari aspekisi adalah sangat baik dengan persentase $95 \%$, aspek media isi adalah sangat baik dengan persentase $100 \%$, aspek media komputer adalah baik dengan persentase $81,6 \%$, aspek desain pembelajaran adalah baik dengan persentase $90 \%$.

Penelitian Amkas (2017) yang berjudul "Pengembangan Media Papan Permainan Ludo Word Gamesiswa kelas IV SDN 1 Banjar Bali Tahun Pelajaran 2017/2018". Hasil pengembangan media papan ludo word game pada kedua ahli isi mata pelajaran bahasa Inggris berpredikat sangat baik (91\%),ahli desain pembelajaran berpredikat baik (85\%), ahli media pembelajaran berpredikat sangat baik (94\%).

Dari beberapa penelitian relevan di atas bisa di jabarkan bahwasanya penting sekali adanya media pemebelajaran, baik itu media inovatif maupun multimedia interaktif dalam pembelajaran Penjaskes khususnya pada materi kesehatan.

\section{KESIMPULAN}

Berdasarkan hasil pengembangan dan validitas yang telah menyatakan bahwa board game monopoli untuk siswa SMP sudah layak dan tervalidasi oleh ahli media

dan ahli materi maka terdapat beberapa saran sebagai berikut :

Bagi guru penjasorkes, agar dapat memanfaatkan board game monopoli sebagai model variasi dalam penyampaian materi kesehatan dalam bentuk media dua dimensi yang berwarna dan bergambar untuk menyampaikan pengetahuan dan informasi baru kepada siswa.

Bagi peserta didik agar memanfaatkan board game monopoli untuk memudahkan dalam mengenali dan memahami materi kesehatan dalam pembelajaran penjasorkes.

Bagi praktis media pembelajaran, agar dapat menguji tingkat keefektifannya dalam pembelajaran dan membuat media pembelajaran yang lebih bervariasi.

\section{UCAPAN TERIMA KASIH}

Dalam menyelesaikan skripsi ini, penulis banyak mendapat bimbingan, dorongan, arahan dan saran dari berbagai pihak. Melalui kesempatan ini peneliti mengucapkan terimakasih kepada:

1. Prof. Dr. I Nyoman Jampel, M.Pd. Rektor Universitas Pendidikan Ganesha yang telah mengayomi segenap civitas akademika UNDIKSHA.

2. I Ketut Budaya Astra, S.Pd., M.Or., Dekan FOK sekaliguspembimbingl yang telah banyak memberikan bimbingan dan saran dalam penyelesaian proposal penelitian ini.

3. I Made Satyawan, S.Pd., M.Pd. Selaku Ketua Jurusan Pendidikan Olahraga yang telah memberi dukungan dalam penyelesaian proposal penelitian ini.

4. I Gede Suwiwa, S.Pd., M.Pd. Selaku Koordinator Prodi Penjas dan pembimbing II, yang telah banyak memberikan arahan dan bimbingan untuk penyempurnaan proposal penelitian ini.

5. Ni Luh Putu Spyanawati, S.Pd., M.Pd. Selaku Pembimbing Akademik yang telah memberi pengarahan, dukungan, serta semangat untuk menyelesaikan tugas akhir ini.

6. Staf Dosen di Program Studi Pendidikan Jasmani Kesehatan dan Rekreasi, yang selama ini telah banyak memberikan 
Jurnal Kejaora: Jurnal Kesehatan Jasmani dan Olah Raga

ISSN: 2541-5042 (Online)

ISSN: 2503-2976 (Print)

Volume 5 Nomor 2, Edisi November 2020

ilmu pengetahuan dan motivasi sebagai bekal menjalankan kehidupan di dalam masyarakat.

7. Staf Pegawai di Fakultas Olaharaga dan Kesehatan, yang selama ini memberikan kemudahan dan kelancaran dalam penyelesaian skripsi ini.

8. Rekan-rekan PENJASKESREK yang telah banyak memberikan dukungan bantuan dalam pelaksanaan penelitian.

9. Keluarga besar tercinta yang telah memberikan dorongan secara moril dan materil sehingga skripsi ini dapat diselesaikan tepat pada waktunya.

10. Semua pihak yang telah banyak membantu dalam pelaksanaan penyelesaian skripsi penelitian ini.

\section{DAFTAR PUSTAKA}

Amkas, S. (2017). Pengembangan Media Papan Ludo Word Game Dalam Pembelajaran Kooperatif Tipe TGT Pada Mata Pelajaran Bahasa Inggris Siswa Kelas IV SDN 1 Banjar Bali Tahun Pelajaran 2017/2018. Skripsi Universitas Pendidikan Ganesha.

Arsyad, A. (2009). Media Pembelajaran. Jakarta: Raja Grafindo Persada.

Depdiknas. (2006). Kurikulum Tingkat Satuan Pendidikan. Jakarta: Depdiknas.

Dimyati \& Mudjiono. (2006). Belajar dan Pembelajaran. Jakarta: Rineka Cipta.

Dimyati \& Mudjiono. (2013). Belajar dan Pembelajaran. Jakarta: Rineka Cipta.

Fiktiany, M. (2007). Efektifitas Permainan Acak Huruf dalam Pengajaran. Jakarta: Rineka Cipta.

Ibrahim , et al. (2004). Media Pembelajaran. Malang: FIP Universitas Negeri Malang.

Maulana, G. R. (2016). Pengembangan Multimedia Interaktif Materi Pola Hidup Sehat Pada Mata Pelajaran Pendidikan Jasmani Olahraga Dan Kesehatan. Tersedia pada https://ejournal.undiksha.ac.id/index.p hp/JJP/article/view/6933 (diakses tanggal 06 September 2019). 